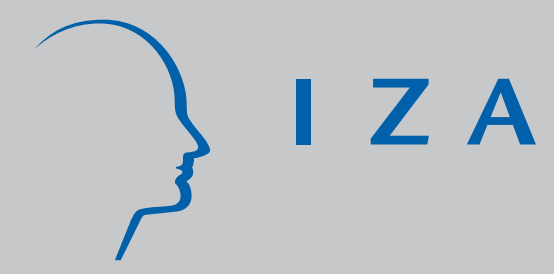

IZA DP No. 343

\title{
Will it Last? An Assessment of the 2001 German
} Pension Reform

Holger Bonin

August 2001 


\title{
Will it Last? \\ An Assessment of the 2001 \\ German Pension Reform
}

\author{
Holger Bonin
}

IZA, Bonn and University of Bonn

Forthcoming in: Geneva Papers on Risk and Insurance

Discussion Paper No. 343

August 2001

\author{
IZA \\ P.O. Box 7240 \\ D-53072 Bonn \\ Germany \\ Tel.: +49-228-3894-0 \\ Fax: +49-228-3894-210 \\ Email: iza@iza.org
}

This Discussion Paper is issued within the framework of IZA's research area The Welfare State and Labor Markets. Any opinions expressed here are those of the author(s) and not those of the institute. Research disseminated by IZA may include views on policy, but the institute itself takes no institutional policy positions.

The Institute for the Study of Labor (IZA) in Bonn is a local and virtual international research center and a place of communication between science, politics and business. IZA is an independent, nonprofit limited liability company (Gesellschaft mit beschränkter Haftung) supported by the Deutsche Post AG. The center is associated with the University of Bonn and offers a stimulating research environment through its research networks, research support, and visitors and doctoral programs. IZA engages in (i) original and internationally competitive research in all fields of labor economics, (ii) development of policy concepts, and (iii) dissemination of research results and concepts to the interested public. The current research program deals with (1) mobility and flexibility of labor markets, (2) internationalization of labor markets and European integration, (3) the welfare state and labor markets, (4) labor markets in transition, (5) the future of work, (6) project evaluation and (7) general labor economics.

IZA Discussion Papers often represent preliminary work and are circulated to encourage discussion. Citation of such a paper should account for its provisional character. 
IZA Discussion Paper No. 343

August 2001

\section{ABSTRACT \\ Will it Last? \\ An Assessment of the 2001 German Pension Reform}

In May 2001, Germany adopted a fundamental pension reform cutting back public pensions and introducing personal pension accounts. The paper critically reviews the reform decisions and evaluates their long-term viability. It is shown that the adjustment of the Public Pension Scheme misses the proclaimed contribution rate and replacement ratio targets already under moderate economic conditions. However, the new private pension plans provide scope for further downsizing state pensions, necessary beyond 2025. As the enacted savings rate target is conservative, individual pensions keep retirement income sufficient even if returns to pension funds are low due to legal restrictions on savings vehicles.

JEL Classification: F22, E66

Keywords: Pension reform, pension funding, fiscal projections, Germany

Holger Bonin

Institut zur Zukunft der Arbeit

P.O. Box 7240

D-53072 Bonn

Germany

Tel.: +492283894303

Fax: +49 2283894180

Email: bonin@iza.org 


\section{Introduction}

Since the unification of the two German states, the system of mandatory pension insurance in Germany, based on a pay-as-you-go scheme since 1957, has been under constant financial pressure. In the year 1997, to balance current pension claims of retirees with current revenue from workers, the contribution to the Public Pension Scheme had increased to 20.3 percent of the payroll, split equally between employees and employers. Afterwards further increasing contribution rates have been avoided only by substantial extra subsidies to the pension system. In fact, the recent increment in federal subsidies, mostly financed through new taxes on the consumption of energy and mineral oil, has been large enough to moderately reduce the payroll contribution to the Public Pension Scheme, to the current rate of 19.1 percent.

In 2000, the government subsidy to balance the pension insurance budget was expected to reach 49.4 billion Euro. This was the largest expenditure item in the government budget, totalling 20.2 percent of all spending. The federal pension subsidy, which is usually justified as a compensation for redistributive elements that contravene against strong tax-benefit linkage characteristic for the German system of state pensions, like credits for child rearing or education and a lift up of low contributions to a minimum level, now covers more than 27 percent of the pension benefits. Translating the fiscal burden related to this pension subsidy into a fictive contribution rate, the actual burden on labour through public pensions would be as high as 25.2 percent of the payroll.

Thus, the Public Pension Scheme is already imposing a high financial burden on contributors and taxpayers. During the first half of the new century, when the German society, in the consequence of permanently low fertility combined with increased longevity, goes through the demographic transition to higher old-age dependency, the financial pressure on government budgets will become even more severe. The long-established fact that the current public pension scheme might be unsustainable with a diminished ratio of contributors to economically inactive transfer recipients, has produced numerous reform proposals aimed at improving the 
long-term viability of the German Public Pension system, ranging from a tax financed minimum pension to advanced funding schemes.

Nevertheless German governments for a long time have introduced only tentative measures stabilising the pay-as-you-go system. The 1992 Pension Reform Act will raise the mandatory retirement age for all workers to 65 between 2001 and 2005, and has reduced hitherto strong incentives for early retirement, but the discount in pensions for premature withdrawal from the labour force is still not actuarially fair. The late Kohl administration had planned to cut future pension growth proportional to observed gains in life-expectancy. This moderate reform, however, was suspended after the Schröder cabinet assumed office in 1998. Instead, the above mentioned cut in payroll contributions through increased government grants to the pension system was installed, with the objective to exploit a supposed double dividend from "green taxes" (Schneider, 1997).

Not until late 2000, the German government did agree on a really substantial reform of the pension system, which, in addition to a whole range of minor amendments, contains two major elements:

- Measures aimed at stabilising the current Public Pension Scheme, by adapting the pension formula to gradually reduce pension growth experienced by both current and future retirees.

- Arrangements for the gradual introduction of non-mandatory, individual pension accounts, dubbed "Riester Pensions" after the government minister in charge, to provide private funded retirement income alongside the state pension insurance.

This article undertakes to give an overview of the current pension reform decisions in Germany, as adopted by parliament in May 2001, and to critically review their implications. The discussion is split into two parts: an analysis of the reform's impact on the long-term viability of the pay-as-you-go based State Pension Scheme; and a critical review of the regulations to build up individual pension accounts, including an illustration of what might be long-term development of the newly introduced private pension plans. 


\section{The Reform of State Pensions}

The first part of the pension reform takes measures to stabilise the contribution rates to the Public Pension Scheme in the long term when pension finances will come under demographic pressure. The declared ambition of political decision makers is to keep the contributions financing state pensions under a level of around 20 percent of the payroll until 2020, and under a level of around 22 percent beyond 2030. To achieve this goal, future pension expenditure growth is moderated by important changes to the indexation formula that links pensions to the earnings development.

\subsection{Moderating pension growth}

In Germany, since the early days of the pay-as-you-go based scheme, state pensions have been indexed to wage growth rather than price inflation. For many, the consequence that pensioners share in productivity growth is one of the key achievements of the German welfare state. While the original earnings indexation formula had taken into account changes of average gross wage income, this policy was abandoned with the 1992 Pension Reform that linked the annual pension adjustment to the development of net wages per worker. The net indexation formula valid until 1999 can be described by

$$
P_{t}=\frac{N E_{t-1}}{N E_{t-2}} \cdot \frac{N P_{t-2}}{N P_{t-1}} \cdot P_{t-1}
$$

where $P_{t}$ represents the (gross) pension in period t, $N E_{t}$ the level of net earnings per worker in period $\mathrm{t}$, in relation to gross earnings, and $N P_{t}$ the net pension level of period $\mathrm{t}$, relative to the average gross pension per retiree.

Within the framework of earnings indexation, net adjustment of benefits in line with equation (1) appeals when pension finances are under demographic pressure. First, if the contribution rates to the Public Pension Scheme increase as the ratio of contributors to beneficiaries worsens, pension expenditure growth is moderated automatically- ceteris paribus, the net income ratio of the employed falls but

\footnotetext{
${ }^{1}$ This is not exactly the actual indexation formula. The presentation is simplified for the sake of argument.
} 
the net income ratio of the retirees (who do not contribute to the system) stays unchanged. Secondly, the indexation formula insures pensioners against falling net income in the consequence of population ageing, for example, if the contributions of pensioners to mandatory health insurance are increased. In this case, ceteris paribus, the net pension ratio of the retired is falling, which leads to a compensating increment in benefits.

However, net indexation of pensions might become problematic in face of income tax reform, as scheduled in Germany for the period 2000 to 2005, and falling pension contribution rates, as made possible by the green tax subsidies to the Public Pension Scheme. Both policies raise the net earnings available to workers while leaving the net amount of pensions (currently de facto tax-free) unchanged, and therefore application of the net indexation rule causes unwanted pension growth. Decision makers answered this unexpected threat by suspending net indexation, and by temporarily adjusting pensions according to consumer price inflation, during the years 2000 and 2001 .

After this transitory period, the current pension reform did not return to the net indexation formula. Instead, pensions will develop according to

$$
P_{t}=\frac{G E_{t-1}}{G E_{t-2}} \cdot \frac{1-\tau_{t-1}^{S}-\tau_{t-1}^{P}}{1-\tau_{t-2}^{S}-\tau_{t-2}^{P}} \cdot P_{t-1},
$$

where $G E_{t}$ represents gross earnings per worker in period $\mathrm{t}, \tau_{t}^{P}$ is the contribution rate to the Public Pension Scheme in period t, and $\tau_{t}^{S}$ stands for the subsidised private savings contribution rate in period t, discussed below. From 2010, the indexation rule (2) is slightly modified, and only 90 percent of gross wages will be taken into account.

To the casual observer, it might appear that reestablishment of the fullearnings link is disadvantageous in comparison to the net indexation rule, because gross wages grow at a faster rate than net earnings in a period of demographic ageing. However, the enacted indexation formula will indeed moderate pension growth.

\footnotetext{
${ }^{2}$ The 90-percent-rule is completely arbitrary. In fact, the rate of gross wage growth indexation was changed several times during the planning stage of the reform.
} 
First, the adjustment factor now safeguards against feedback effects from the prospective income tax cuts. Further, the new procedure discards the partial insurance of retirees against declining net pensions. Higher contribution rates to mandatory health and long-term care insurance of pensioners are not compensated by concomitant changes of gross pensions. Finally, as is easy to show analytically, the yearly pension growth rate calculated on the base of equation (2) is more elastic with respect to marginal increments in the contribution rate to the Public Pension Scheme, compared with the old adaptation formula. This means that for any given increase in pension contributions, the new regime generates a higher discount in the subsequent pension adjustment.

Thus, technically the enacted change of the pension adaptation rule is capable to curb future appreciation of pension contribution rates. The empirical question is whether the moderation of pension expenditure growth is large enough to keep contribution rates below the promised long-term level of 22 percent. A second, closely related question is how the new indexation strategy will affect the net income position of pensioners relative to workers. One feature of the now obsolete net indexation formula is that the net replacement rate of pensions, which is the amount of average net pensions in relation to the amount of average net wage income, stays relatively stable over the time. With the return to gross wage indexation this is not guaranteed anymore- since pensioners are not compensated for increasing social insurance contributions, the net replacement rate, reported 70 percent in 2000, could fall.

This possibility has attracted much public concern in Germany, although a lower fraction of net income replaced by state pensions by no means implies that disposable income of pensioners does fall in absolute terms. Official projections of the net replacement rate after the reform seem to indicate that the future deteriora-

\footnotetext{
${ }^{3}$ In German pension law, the term net replacement rate refers to a very specific construct: It describes the net pension level of a fictive "standard" pensioner with 45 years of contributions who always earned exactly the average income per worker, relative to the current average net wage income per worker. As contribution histories are on average shorter than 45 years, empirical net replacement rates tend to be lower than the statistical figure of 70 percent. Thus, the German state pension scheme is somewhat less generous than the reported net replacement rate might suggest.
} 
tion of pensioners' net income position relative to workers will be small. Nevertheless, the current pension law includes a rule that forces decision makers to take countermeasures as soon as the net replacement rate falls below a guaranteed level of 67 percent.

\subsection{Testing the consistency of the state pension reform}

In order to judge the soundness of the current regulations for the state pension scheme one has to test whether the two central objectives announced by its reformers, to stabilise the contribution rate below what is considered as an excessive level and to keep the net replacement rate above the guaranteed level, can be reached at the same time or not. This test requires a long-run projection of what might be the financial development of the Public Pension Scheme. The results on future contribution and net replacement rates presented in the following are derived applying a projection of age-specific individual pension benefits under the current legal status quo to a demographic forecast. From this, contribution rates are derived endogenously to balance the pay-as-you-go budget, taking into account the age distribution of contribution payments and the time path of the federal subsidy complementing contribution revenue, tax financed by assumption. For a comparison, the same calculation is also made based on the previous legal setting.

Specifying the pension insurance model, it seems reasonable to select a parameter combination that might be dubbed as status quo set-up. In this scenario, basically all key demographic and economic parameters are held constant at their current levels. More specifically, the demographic projection claims that fertility stays below the replacement rate, at the 1999 level of 1.4 children per woman, and that net immigration to Germany equals the post-war average of 200,000 persons per year. With regard to mortality, until 2030 a very moderate increase in age-specific survival rates is considered, which translates into a gain in life expectancy conditional on age 60 of about two years for both men and women. Under these assump- 
tions, old-age dependency, measured as the number of agents aged 65 or older per hundred individuals of employable age between 20 and 65, increases from 26 in 2000, to 44 in 2030 .

Designing the future economic environment, economic growth is set to a constant rate of 1.5 percent p.a. in real terms. Unemployment and labour force participation rates are kept at their current level. Further, the effective retirement age is kept constant except for the impact of the behavioural changes induced by the measures of the 1992 Pension Reform Act making early retirement more costly (Börsch-Supan 1998). Compared with the long-term economic forecasts used by government authorities, which assume a drastic reduction in unemployment (basically to the natural rate) and rising labour force participation, in particular of females, this is certainly a conservative setting. Still, the following projection does not seem overly pessimistic. First, it is misleading to conclude that a declining population of employable age, the consequence of below-replacement fertility, would necessarily reduce unemployment, as it is assumed by the government projections. This view ignores the role of labour demand for unemployment, as well as the possibility of qualification mismatch.

Secondly, although it is likely that labour force participation will continue to grow in Germany, it is much less likely that this development will be to the benefit of the Public Pension Scheme. Rather on the contrary, the experience of the last decades suggests that the fraction of employment covered by mandatory social insurance will decline further, as there is a strong trend toward non-standard forms of employment. Finally, the mortality scenario seems very optimistic given the observed trend in longevity. The status quo setting is much more cautious than the latest demographic projection provided by the Federal Statistical Office (2000), for example. Higher old-age dependency as a result of more substantial ageing from the

\footnotetext{
${ }^{4}$ In this case, the forecast of contribution rates is more complex, as pension expenditure by net indexation is directly linked to the financial development of mandatory health and long-term care insurance. For details on the comprehensive social insurance model underlying the projections, see Bonin (2001)
} 
top could seriously increase the long-term imbalance of state pension finances (Besendorfer et al. 2000).

Figure 1 displays how the contribution rate to the Public Pension Scheme develops according to this altogether moderate economic and demographic scenario. Despite the slower pace of pension expenditure growth achieved by the current pension adjustment formula, the long-term increase of contribution rates due to demographic aging is large. The maximum contribution rate is reached around 2035, at some 23.3 percent of the payroll. Therefore, although this is about two percentage points less than under the former legal arrangement, and substantially less than it has been predicted up till now by most analysts of German pension finances (Sinn and Thum 1999), the current reform of pay-as-you-go pensions fails to meet the target contribution rate of 22 percent beyond 2030 .

Sensitivity tests indicate that it would require substantial growth of employment, or more precisely of employment covered by the state pension system, in the next two decades, to realise the stabilisation goal during the period of maximum demographic pressure. $\mathrm{B}$ On the other hand, in a probably more adequate demographic setting based on more substantial mortality decline, contribution rates to the Public Pension Scheme would increase until the middle of the century, and finally exceed 25 percent.

Figure 1 also shows that the contribution rate of 20 percent announced by government authorities for the year 2020 is fairly realistic. However, it is evident that this is not exclusively a consequence of the current policy change, as the now obsolete indexation formula would lead to a very similar time path of contributions over the medium term. The initial stabilisation of contribution rates is also the result of the substantial expansion of subsidies to the Public Pension Scheme associated with the current green tax policy. The increased financial support, together with a comparatively favourable demographic environment, keeps contribution rates below

\footnotetext{
${ }^{5}$ Note that rapid expansion of employment is only temporarily beneficial, if in the period of highest demographic pressure. In the longer term, the alleviating impact vanishes when the extra contributors begin to retire.
} 
the current level throughout the next two decades. From a political perspective, given the long-term failure of the reform to hit the stabilisation target for state pensions, this could be an unfortunate development- the apparent stability of pension finances might prohibit further reform in good time.

Beyond 2030, according to the status quo projection, decision makers could avoid contribution rates above the target level only by raising government subventions, or by further reducing the level of state pensions. The latter, however, would be inconsistent with the net replacement rate guarantee given with the current reform. This is evident inspecting Figure 2, which shows the time path of the net pensions relative to net income as predicted under the new and old regulations.

The modified indexation formula rapidly reduces the quota of net income replacement, as claimed by many opponents of the reform. In the period of maximum demographic pressure, around 2035, the net replacement level is below 63 percent, substantially less than the guarantee quota of 67 percent, whereas under the now abandoned regime, the net replacement level would stay well above the rate calling for political intervention. Under the current reform, the pension level remains close to 67 percent only if one relies on a statistical construct of net labour earnings treating private savings contributions like taxes. In economic terms, however, this is not a sensible conception of net income. As private savings are voluntary, they are one form to consume current income that competes with rather than crowds out consumption. This means, the decision to save does not reduce individual consumption opportunities but only postpones consumption to a later stage of life. Nevertheless government authorities seem to have based their pension guarantee on this dubious income construct.

Note that the net replacement level already falls substantially in the first years of the projection. The most significant drop comes in the very first year when pension adjustment according to consumer price inflation lowers the relative net pension level by more than one percentage point. In the following years, the scheduled income tax reform combined with falling contributions to the Public Pension Scheme raises net earnings of workers while at the same time annual pension 
growth is moderated by the new indexation formula correcting the development of gross earnings for gradually increasing private savings contributions. In the longer term, relative net pension decline is explained by the fact that pensioners are not compensated for rising health and long-term care contributions by the new indexation rule.

\subsection{Internal rates of return}

A useful strategy to summarise the sequences of state pension contributions and benefits on display in Figures 1 and 2 is to calculate the corresponding internal rates of return. This will also allow to illustrate the impacts of the current reform effort on different generations. The internal rate of return is defined as the interest rate that balances the present value of individual contribution to the Public Pension Scheme over the life-cycle and the present value of aggregate pension benefits received in exchange. Put differently, the internal rate of return measures the average return on the investment into pensions through mandatory contributions. It is therefore an indicator for the individual profitability of being a member of the state pension system.

Internal rates of return are mostly computed tracking typical pension biographies, which accounts for heterogeneity within birth cohorts (Schnabel 1998). In the following, an alternative approach is used based on the intertemporal budgeting method for public sector finances known as generational accounting (Auerbach et. al. 1991, 1992). Generational accounts are defined as the present value of payments to the public sector net of transfers received made by representative members of different birth cohorts over their life-cycle. The internal rate of return to individual payments is given by the constant discount factor yielding a zero generational account. In our context of the pay-as-you-go based Public Pension Scheme in isolation, the generational accounting approach to internal rates of return has the advantage that it allows to consider the various feedbacks between the different branches

\footnotetext{
${ }^{6}$ This procedure to measure internal rates of return for state pension contributions was suggested by Raffelhüschen (1998), and has been elaborated by Bonin (2001).
} 
of social insurance. In addition, it makes it comparatively easy to take into consideration that the individual investment into state pensions not only consists of payroll contributions, but also of tax payments financing the government public subsidy. As the exact incidence of the subvention is unknown, it is assumed in the following that the subsidy is financed through a proportional fraction of tax revenue. This implies that also the retired make an -indirect-contribution to pension financing.

Figure 3 displays the internal rate of return to contributions (and tax payments) paid to the Public Pension Scheme for generations born after 1980, before and after the current reform. Obviously the new regulations hardly change the pattern of generational redistribution generated by pay-as-you-go financing in the course of the demographic transition. Young generations are still confronted with rapidly falling returns to their investment in the state pension system. Compared to the cohort of 1980, the profitability of state pension contributions has declined by about one third for a representative newborn of 2000. At the minimum, for generations born during the next decade, pension contributions will create a return of less than 0.8 percent per annum, which is probably much less than the return to a secure investment on the capital market would be.

The moderate gain in profitability for the very young and future generations achieved by the current reform comes at the cost of reduced profitability for older generations. In Figure 3, this is evident for cohorts close to entering the labour force, who are worse off compared to the previous situation. As shown by Schnabel (2001), the reduction in profitability will be even higher for generations already in the labour force, who do not fully profit from the moderation of contribution rates but are increasingly hurt by the moderation of pension growth. Hence the current reform might have an unwanted feedback- by reducing the profitability of the Public Pension Scheme for current contributors, there is a risk to accelerate the ongoing

\footnotetext{
${ }^{7}$ The tax part of the generational accounting model is derived parallel to the comprehensive generational accounting study for Germany presented by Bonin et al. (1999). Of course, one could argue that the pension subsidy crowds out government transfers and public investment, or raises government debt. To the extent that the latter is indeed the case, a fraction of the current fiscal burden from state pensions is shifted to future generations, reducing their internal rate of return to the benefit of current generations.
} 
trend of individuals converting to non-pensionable forms of employment. This would further reduce the profitability for agents staying in the system.

To summarise, an evaluation of the long-term financial development of the Public Pension Scheme shows that the current reform of state pensions does not hit the reform targets. Under what occurs to be a not too pessimistic development, the contribution rates required to maintain state pensions might exceed 23 percent of the payroll beyond 2030, whereas at the same time, the net replacement quota provided by state pensions effectively stays below the level currently regarded tolerable by policymakers. In such a situation, the only remaining option under pay-as-you-go financing would be further increasing government subsidies to the system. However, considered the already high level of grants that reduces the profitability of the Public Pension Scheme indirectly through the federal budget, this does not seem a sustainable policy. If the public subsidy cannot be increased, however, the contribution rate target and the net replacement rate target are inconsistent.

What way out of this quandary? Considered the relative generosity of the state pension system, one might expect that policymakers will eventually tolerate a more substantial cut of public pensions than is currently envisaged, also if this means that the all-important net replacement quota would fall further below the level regarded feasible today. This is possible, as complementary income from the newly introduced private pension accounts, which we now discuss, becomes increasingly available to pensioners.

\section{Introducing Personal Pension Plans to Germany}

While the changes in the Public Pension Scheme described so far appear as the latest step in a long series of attempts to make pay-as-you-go pension financing viable in the long term, the second element of the current reform introducing private pension plans is a fundamental change- in fact the conditions for individual pension accounts make a step toward a Anglo-Saxon style approach to funding Social Security. This is a remarkable development considered that there is strong emotional at- 
tachment in Germany to the long-lasting pay-as-you-go principle. In fact, the reform plan has met a strong critical reaction. It appears to many that the government support of private pension fund provision weakens "solidarity between generations" provided, as it is claimed, by the Bismarckian type of social insurance.

\subsection{Incentives for voluntary savings}

Under the now enacted rules, workers, up to the earnings cap on contributions to the Public Pension Scheme (about $€ 57,300$ at present), would start saving one percent of their gross wage into authorised private insurance or occupational pension plans in 2002 and 2003. This amount is increased in each year of the introductory phase, reaching the final value of four percent in 2008. While savings into individual pension accounts are voluntary, the government has created a complex system of incentives to encourage private provision for old-age combining tax deductions and direct payments.

First, the introduction of private pension accounts is complemented by a move to the internationally compatible system of deferred taxation, which means that voluntary savings contributions to private pension plans (unlike mandatory contributions to the pay-as-you-go scheme) are completely exempt from taxation but pensions are not. To be precise, at the final stage of the reform, it will be possible to deduct any amount up to four percent of the earnings cap on pension contributions from taxable income.

Secondly, to support low income earners who would not benefit from deferred compensation, individual savings will be lifted up by a direct savings allowance provided by the government. This allowance, starting with an amount of $38 €$ per capita in 2002, reaches $154 €$ per year when the reform is completed after 2008. Spouses who do not work are equally qualified for the standard allowance, provided that the partner pays into a separate private savings plan for them. Furthermore, an extra allowance is given for each child, worth $185 €$ per year at the final stage. Thus the reform includes a strong family element, which could be justified arguing that by 
the rising of a child an above-the-average contribution is made to the pay-as-you-go pension scheme (Sinn 1997).

Complementary savings allowances by the government are given to anyone proving to put the targeted rate of gross income into a private pension plan, irrespective of the income level. (Individuals saving less than the target rate would get only a fraction of the standard allowance.) Nevertheless, effectively the subsidisation of private savings contributions has been limited to individuals with lower income. This is achieved through a specific tax rule: Whenever the tax refund due to private savings contributions is larger than the amount of the direct government payment, the refund is reduced by exactly the amount of the latter. On the other hand, if the direct savings-allowance is larger than the would-be tax refund, no tax rebate is given.

The impact of this policy on the effective subvention of personal pension plans is illustrated in Figure 4 which shows, for an unmarried individual without children who saves exactly the targeted amount, the absolute level of the government subvention to the private provision for old-age, according to the personal pension and tax regulations valid in 2008, as a function of gross income. For simplicity, deriving taxable income from gross income, it is further assumed that only standard deductions apply, and that there are no other sources of income.

Under these conditions, gross earnings below around 11,200 $€$ are not taxed at all, and the individual receives the full savings allowance of $154 €$. The latter still holds for individual earnings in the range between $11,200 €$ and 15,300 $€$. In this income bracket, the tax advantage from a deduction of individual savings contributions remains smaller than the direct government payment. However, not being eligible for the tax refund anymore involves a cost- as the individual does not get tax refund for her private savings, the effective subsidy is reduced by the amount of the latent tax advantage.

It is important to note that in economic terms, the tax refund is not a substitute for the direct subsidy, unlike what is often suggested by policymakers. The income tax rebate is part of the deferred taxation policy. Cutting it implies that some 
of the provision for old-age, intended to be taxed later on, is actually made from taxed income. In the earnings range from $11,200 €$ to $15,300 €$, this disadvantage is more than compensated by the direct savings allowance, but the level of effective subvention rapidly declines. For earnings above $15,300 €$, the immediate subsidisation of savings becomes in effect zero, because the loss of tax rebate is equal to the direct subsidy payment.

To generalize, ${ }^{8}$ for individuals not eligible for a savings subsidy the parallel system of direct government payments and additional tax breaks appears unnecessarily complex. Tax allowances would be sufficient. An equivalent but more straightforward solution to provide the intended subsidy would be first to give full tax refund according to individual savings to all taxpayers, and then to lift up the refund for taxpayers whose tax rebate is smaller than the target level.

Figure 5 illustrates, for the type of household analysed before, the fraction of personal pension savings that is financed by the government in the current period, either through effective subsidies or a tax rebate within the framework of deferred taxation, depending on gross income. It demonstrates that for individuals with very low income, the direct government payment can match individual savings contributions almost Euro by Euro,, although the support quota would usually range between 30 and 40 percent of total savings in the bottom part of the empirical income distribution. When the effective subsidy expires beyond 15,000€, the government still provides around one fifth of the savings target for the single household.

For individuals with higher income, the government's share in savings gradually increases, as a consequence of the progressive income tax system. Considering the policy of deferred taxation, it is clear that this development does not

\footnotetext{
${ }^{8}$ Of course, one could draw pictures parallel to Figure 4 for more complex household types. In general, the income bracket characterized by declining effective subsidies is shifted upwards for couples, and with the number of children. At the same time, the marginal subsidy reduction rate tends to be smaller, so that the income bracket becomes wider.

${ }^{9}$ The subsidy quota of 100 percent reported in Figure 5 could not occur in practice. Although it might be the case that the savings allowance is larger than the imposed savings target, there exist special regulations ensuring that individuals will always make at least some savings contribution. Our model abstracts from this complication.
} 
imply that individuals in the upper part of the earnings distribution would necessarily receive more public support of their private savings accounts compared with agents earning medium income. (Individuals in the bottom part obviously receive a preferred treatment, as they are the only to benefit from a true subsidy.) In general, current recipients of high income would receive high private pensions in the future, and therefore the current progressive tax advantage might only compensate for progressive taxation in old-age. Empirically, the extent to which deferred taxation of savings contributions is actually progressive depends on the development of taxable income (and average tax rates) over the life-cycle. This is almost impossible to predict from today's perspective, as appropriate tax rules for old-age income are an issue not finally addressed by the German government.

The example studied in Figures 4 and 5 clarifies that the government subvention of individual retirement accounts is effectively regressive, as would be the intention of a reformer concerned about the distributive implications of the policy change. On a more conceptual level of argument, however, one might question the policy of state subsidies to build up personal pensions for the recipients of low earnings, which at the final stage are estimated to burden the public budgets by about 10bn Euro each year. In principle, it is possible that this amount would create a higher return if invested alternatively into reducing government debt. To the extent this is the case, however, the subvention policy, from an intertemporal perspective, does not reduce the overall financial liabilities of the public sector. Note that the strategy of debt reduction is not necessarily in conflict with the long-term distributional objective of the subvention policy: To maintain an adequate income in oldage for low-income earners, standard instruments of social welfare could be used to lift up the -soon reduced- state pensions to a guarantee level. This policy could be financed by the lower interest due after paying off government debt.

Whether reducing (government) dissavings is superior to subsidising (personal) savings is in practice a matter of political and economic circumstances. Politically, subventions to individuals have the advantage of putting funds out of reach for decision-makers. A long-term commitment to repay government bonds, in con- 
trast, is easy to break under financial pressure. In economic terms, a necessary condition for the debt policy to be preferable is that the interest rate on government bonds is larger than the return to private savings. One would expect that this condition does not hold empirically. With free choice of portfolio and perfect capital markets, agents usually realise a higher return on savings than the market rate on government bonds, if at an increased risk.

However, this is by no means guaranteed for the specific investment into personal savings accounts. First, low-income earners benefiting from the subsidy could have imperfect access to capital markets, for example, because of incomplete information or a limited choice of investment alternatives as the amount to invest is small. Secondly, the return to subsidised savings could be substantially lower than normal, as a consequence of the highly selective investment criteria imposed by the current regulations. This remark leads us to the savings vehicles supported by the reform.

\subsection{Private savings vehicles}

To regulate individual provision for old-age, the bill introducing the Riester Pensions, after many alterations in the course of the parliamentary procedure, specifies a long list of features to be satisfied to make voluntary savings contributions eligible for government support. The rules set have some attractive features but some of the criteria appear too restrictive to make the funded pension provision really attractive. In particular, to qualify for government support, the individual pension funds, which cannot be distributed before the age of 60 , will have to

- provide a life-long annuity, or at least a fixed yearly payment of not more than 3.6 percent of the capital, if annuitisation is deferred until the age of 85 . So far, there are no rules regarding whether the pension payments must be indexed, although contracts providing a growing benefit are certainly not prohibited.

- guarantee that the nominal value of the fund at retirement is at least equivalent to the accumulated contributions. 
All suppliers of individual pension funds will be controlled by a regulatory agency certifying financial products that at least formally meet the support criteria. Both the obligation to annuitisation and the contribution guarantee impose a cost on the consumer. For example, it is currently illegal to offer annuity contracts for investment companies, who would have to buy this service externally on the insurance market. Furthermore, the strict requirement of pension annuitisation might be welfare reducing for the consumer as it might prevent an optimal allocation of consumption during old-age- individuals would in general prefer higher payments at the beginning of retirement, and perhaps sometimes a lump-sum disbursement of the full savings amount.

Although the security of savings contributions is promised only in nominal terms, it might be difficult for investment funds to invent products with a moneyback guarantee. It is not settled yet to what extent funds could make use of derivatives to hedge the contribution liability, or if they have to establish sufficient book reserves. Still, the fact that investment-type fund products have to be combined with insurance policies could lead to substantially lower rates of return on the individual savings accounts, as the range of savings vehicles is limited. This cost of consumer protection is difficult to justify, given that retirement income remains adequate for most individuals even if their individual pension plan is a failure, given the still quite generous level of state pensions.

An issue of public critique is that the above support criteria are not compatible with the favourite type of provision for old-age in Germany, which is the purchase of real estate. This is only a consequential decision, considered the difficulties to apply deferred taxation to the returns to housing. Moreover, it is practically impossible to annuitise real estate unless the property is handed over to the insurer after death. ${ }^{10}$ A last-minute amendment to the savings regulations has provided some indirect support of housing property, however- if they acquire real estate for their own use, individuals have the right to temporarily withdraw up to 50,000 € from

\footnotetext{
${ }^{10}$ The current law actually includes this as a viable option eligible to government support.
} 
their private savings account, under the condition of returning the loan until the age of 65. This possibility is highly profitable as the loan is obtained free of interest.

While the conditions to be satisfied by private funded pension provision to get government support appear unnecessarily restrictive, still a wide range of institutional arrangements is allowed. As the regulations in principle do not discriminate in favour of one particular provider of personal pension accounts, there would be competition between at least three types of suppliers:

- Insurance companies, having a head start over other providers, as there is a long tradition in Germany of buying life insurance that provides a type capital pension in old-age. It is not by coincidence that the planned supervision of pension funds is designed parallel to the regulatory controls for (life) insurance companies.

- Banks and investment companies offering savings plans combined with insurance elements for old-age, to satisfy the annuity condition.

- Occupational pension schemes, which have been in decline in recent decades but might come into new life as the current pension reform has made provisions to install "proper" pension funds based on defined contributions.

The different parties have started contesting the market for the Riester Pension Plans immediately after the pension reform was passed into law. Although none can offer a product certified for government support so far, gaining the lead when funded pension provision is phased in is essential, because once having selected a savings plan consumers would not easily change to a different scheme.

It is too early to ascertain how the competing suppliers of Riester Pensions will succeed. One might expect, however that schemes within the framework of occupational pension provision will get a particularly good start, for a series of new regulations creates attractive conditions for pension funds. For employers, the option to offer for the first time defined-contribution plans provides the opportunity to replace the prevalent but disadvantageous practice to provide occupational pensions via book-reserve schemes burdening the balance sheets of the sponsoring company. This transition receives favourable tax treatment- payments or assets transfers made 
to a pension fund by an employer, in addition of being deductible as operating expense, are treated as tax-free income of the employee. This implies that commitments based on book reserves can be transferred to a pension fund without becoming liable for social-security contributions.

For the employee, the attractiveness of occupational pension plans has been strengthened by shortening the vesting period (to five years), and by granting a legal right to participate in deferred compensation agreements (Entgeltumwandlung). Any voluntary sacrifice of current salary that is put into a pension fund is tax-free, even above the listed savings contribution rate, up to a threshold equal to four percent of the earnings cap on social-security contributions. While employees are free to bargain with their employers on deferred compensation schemes (which are attractive for the latter, keeping part of the salary free from social-security payments), trade unions will seek to exploit these rules by assigning a fraction of the negotiated pay increase to collective pension funds on the industry level.

Making capital-covered retirement provision part of the collective bargaining process could appear attractive to many Germans sceptical of individual pension plans. However, there is a risk: If private schemes are made largely redundant in this way, this would limit the competition among the suppliers of private provision for old-age, and seriously restrict the range of savings vehicles invented to meet the criteria for government support. In any case, the now allowed defined-contribution plans are not equivalent to Anglo-Saxon style pension funds, because they, like any Riester Pension Plan, must offer guaranteed minimum benefits. This obligation either burdens employers who continue to bear risks from offering a company pension scheme, or reduces the investment return, as pension-scheme managers would chose, for example, only a lower quota of shares in their portfolio.

\subsection{The returns to private savings accounts}

Given that the restrictions on savings vehicles included in the current set of rules for the provision of private funded pensions might substantially reduce the return to individual savings contributions, an important question is whether the scheduled 
savings rate is nonetheless sufficient to compensate current workers for the reduced replacement of net income provided by pay-as-you-go based state pensions.

This question can be answered by a simulation of the long-term development of the private savings accounts. The following projection supposes that all individuals covered by state pensions always make exactly the envisaged saving contributions to the private system and will start withdrawing savings from their pension fund at the retirement age of 65. Regarding annuitisation, it is assumed that the pension scheme is indexed to productivity (or gross wage) growth, set to constant rate of 1.5 percent per annum in real terms. Computing the amount of the funded pension in the year of entry to retirement before taxes, the average life expectancy conditional on age 65 observed in each period is taken into account. ${ }^{11}$ Finally, net private pensions are derived by deducting predicted health and long-term care contributions and applying a constant average tax rate of 15 percent, which is necessarily ad hoc because the taxation rules that will be applied to retirement income are still undecided.

Figure 6 displays the resulting development of the actual net replacement level faced by future pensioner cohorts in the year of entry into retirement, after the inclusion of the (net) annuity from the private savings plan, for alternative real rates of return on pension funds. For a comparison, the net replacement quota of the state pension system in isolation is repeated. Although the accumulation of private funds takes time, annuities get substantial shortly after the phasing in of the private scheme completed. The cohort retiring in 2015 could already replace around one percent of current average net earnings with returns from their pension account. However, this is not sufficient to compensate the sharp decline of state pension levels in the first years after the reform, so that the total benefit level would stay below the level of 67 percent targeted by policymakers.

\footnotetext{
${ }^{11}$ In practice, the level of private pensions will vary substantially by gender corresponding to differences is longevity. With a policy of voluntary savings, it is not possible to avoid this perhaps problematic outcome by forcing insurers to employ uniform life-tables to compute annuities. Depending on whether gender specific contributions are allowed or not, this requirement would force either bad or good risks out of the market, as they are not offered an individually fair contract.
} 
As individual savings accounts are maturing, personal pension provision takes off after 2015. Even supposed a very low return to private funds of one percent p.a. in real terms, net retirement income would exceed the all-important 67 percent level of current net earnings beyond 2025. In the very long-term, after 2050, the mature joint system of state and private pensions converges to a net replacement level around 71 percent, which is even higher than today. If one allows less conservative assumptions on what could be the future real rates of return to individual pension funds, pensioners' relative income position is getting of course even more favourable over time. With constant real returns of two (three) percent, the target replacement level is surpassed again in 2020 (2018), and the overall net income quota exceeds the initial value beyond 2036 (2029).

Are individuals forced to save too much? Considered that the pay-as-you-go based system misses the contribution rate target already under quite moderate economic and demographic developments, the answer to this question is hardly yes. Rather on the contrary, only the introduced savings rates would leave enough scope to downsize pay-as-you-go based state pensions beyond 2030 when the contribution rate promise becomes unsustainable already under moderate economic and demographic conditions. In this situation private pensions, even if the return to individual savings plans were very low, would provide sufficient income to reduce the state pension level further and keep to the 67 percent objective for overall pensions.

Because savings contributions are voluntary, it is possible that the empirical development of replacement levels will turn out much less favourable. Individuals might chose not to save the full scheduled rate and therefore net income replacement might be smaller than on display in Figure 6. However, this would not invalidate the previous argument. Individuals who would voluntarily decide against postponing consumption to old-age, as required by the reform, despite knowing that state pension levels will be reduced, appear as currently over-insured by mandatory pay-as-you go pensions. 


\section{Conclusion}

With the recent pension reform combining a reductions of the state pension scheme with subsidised voluntary savings to build up personal pension funds, German policymakers have agreed on what are certainly the most radical changes of pension financing since the introduction of the pay-as-you-go based Public Pension Scheme in the 1950s. However, as perhaps inevitable for a political innovation of this significance, it is unlikely that the reforms will pass the test of time unchanged. Many of the details are the results of hasty political compromise, which might explain why the measures take many steps in the right direction but are too cautious at closer inspection.

In particular, the policy to downsize the pay-as-you-go pension scheme is not far-reaching enough. Already under moderate economic and demographic developments, contribution rates to the mandatory pension scheme are still surging when demographic pressure becomes severe. A commitment to further reducing state pension levels beyond 2030 would be a more adequate policy. The early proclamation of realistic state pension objectives also creates additional incentives for voluntary savings, which would recover most of the enforced loss of state pensions even if returns are small. While the scale of the Riester Pensions seems sufficient, the private pension funds on the whole are over-regulated. This concerns both the complex subsidisation of low-income earners through parallel direct payments and tax advantages and the qualification criteria for government support, which could protect consumers too much at the cost of reduced rates of return.

Beside that, there are other unresolved problems. The issue of how to install the deferred taxation scheme has been postponed, certainly as taxing pensioners is not a vote winning strategy. Moreover, the transition to a partially funded system involves difficult issues of intergenerational redistribution. While the internal rates of return of the pension system, including annuities, are given a boost by the reform, they still vary substantially across generations. Distribution policy might have to address two groups in particular: pensioners retiring during the next decade, who are 
burdened by the substantial reduction of pension levels in the early years of the reform but will not have the time to accumulate compensating savings; and cohorts born in the next decade who will face the peak of pay-as-you-go contribution rates in the period when they are most productive.

But already passing the current reform into law required years of considerable political energy. Anything more, alas, will have to wait.

\section{REFERENCES}

AUERBACH, A, J. GOKHALE, and L. KOTLIKOFF (1991) Generational Accounting: A Meaningful Alternative to Deficit Accounting, in: D. Bradford (ed.), Tax Policy and the Economy, Vol. 5, Cambridge: MIT Press, pp. 55110.

AUERBACH, A, J. GOKHALE, and L. KOTLIKOFF (1994) Generational Accounting: A Meaningful Way to Evaluate Fiscal Policy, Journal of Economic Perspectives, 8, pp. 73-94.

BESENDORFER, D., H. BONIN, and B. RAFFELHÜSCHEN (2000), Reformbedarf der Gesetzlichen Alterssicherung bei alternativen demographischen Prognose, Hamburger Jahrbuch für Wirtschafts- und Gesellschaftspolitk, 44, pp. 105-122.

BONIN, H. (2001), Generational Accounting, Theory and Application, Berlin: Springer.

BONIN, H., B. RAFFELHÜSCHEN, and J. WALLISER (1999), Germany: Unification and Aging, European Economy, 1999(6), 71-85.

BÖRSCH-SUPAN, A (1998), Germany: A Social Security System on the Verge of Collapse, in: H. Siebert (ed.), Redesigning Social Security, Tübingen: Mohr, pp. 129-159.

FEDERAL STATISTICAL OFFICE (2000), Bevölkerungsentwicklung Deutschland bis zum Jahr 2050 - Ergebnisse der 9. koordinierten Bevölkerungsvorausberechnung, Wiebaden: Metzler-Poeschel.

RAFFELHÜSCHEN, B. (1998), Interne Renditen gemäß Generationenbilanz, in: Deutsches Institut für Altersvorsorge (ed.), Renditen der gesetzlichen Rentenversicherung im Vergleich zu Alternativen Anlageformen, Frankfurt, pp. 36-49.

SINN, H.-W. (1997) The Value of Children in a Pay-as-you-go Pension System: A Proposal for a Partial Transition to a Funded System, CES Working Paper no. 141, University of Munich. 
SINN, H.-W. and M. THUM (1999), Gesetzliche Rentenversicherung, Prognosen im Vergleich, Finanzarchiv, 56, pp. 104-135.

SCHNABEL, R. (1998) Rates of Return of the German Pay-As-You-Go System, Finanzarchiv, 55, pp.374-399.

SCHNABEL, R. (2001), Die Rentenreform 2001, Gutachten zur Rentabilität, Generationengerechtigkeit und den wirtschaftlichen Annahmen der Regierung, Cologne: Deutsches Institut für Altersvorsorge.

SCHNEIDER, K. (1997), Involuntary Unemployment and Environmental Policy: The Double Dividend Hypothesis, Scandinavian Journal of Economics, 99, pp. 45-59. 
Figure 1: Payroll Contribution Rates to the State Pension System
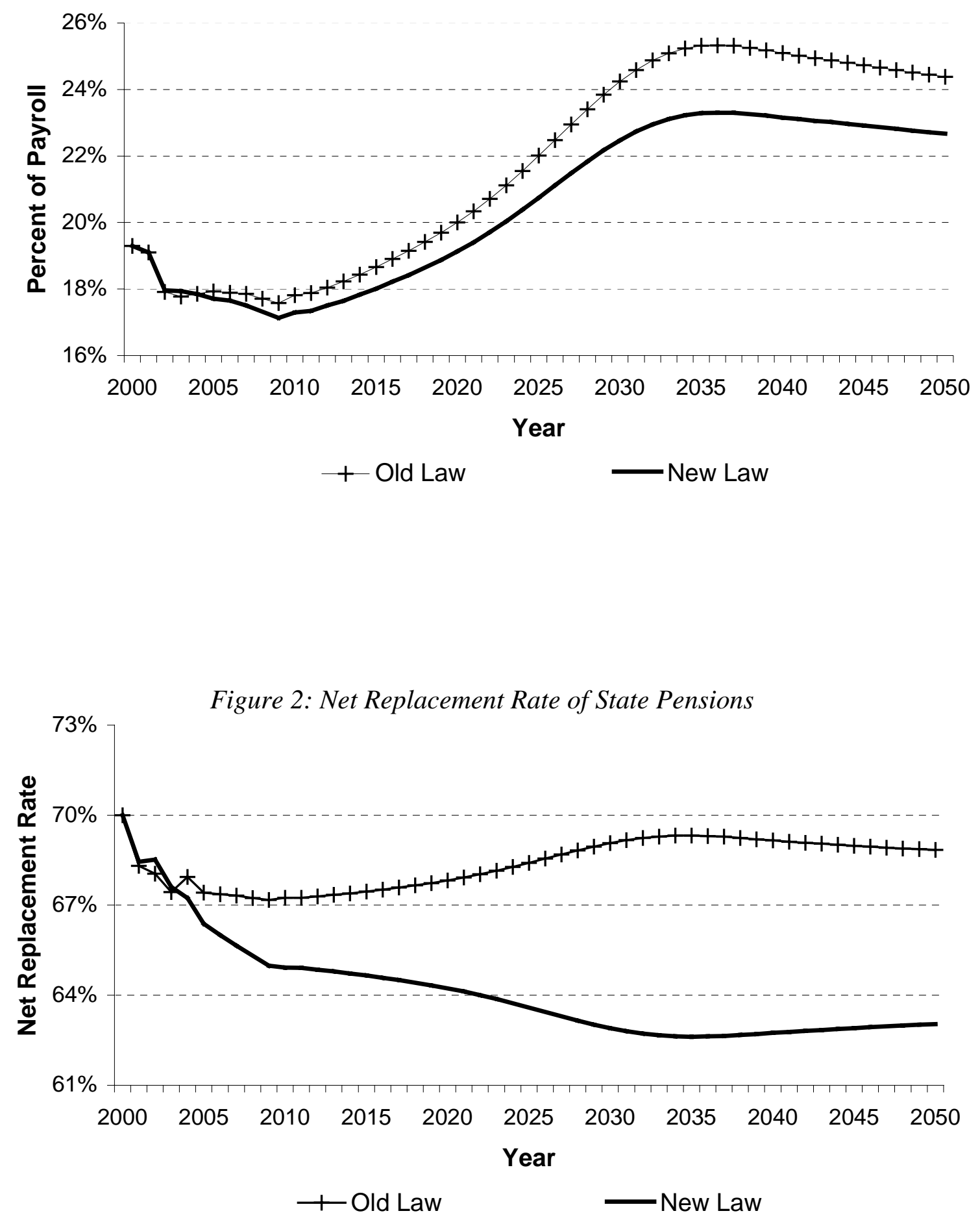


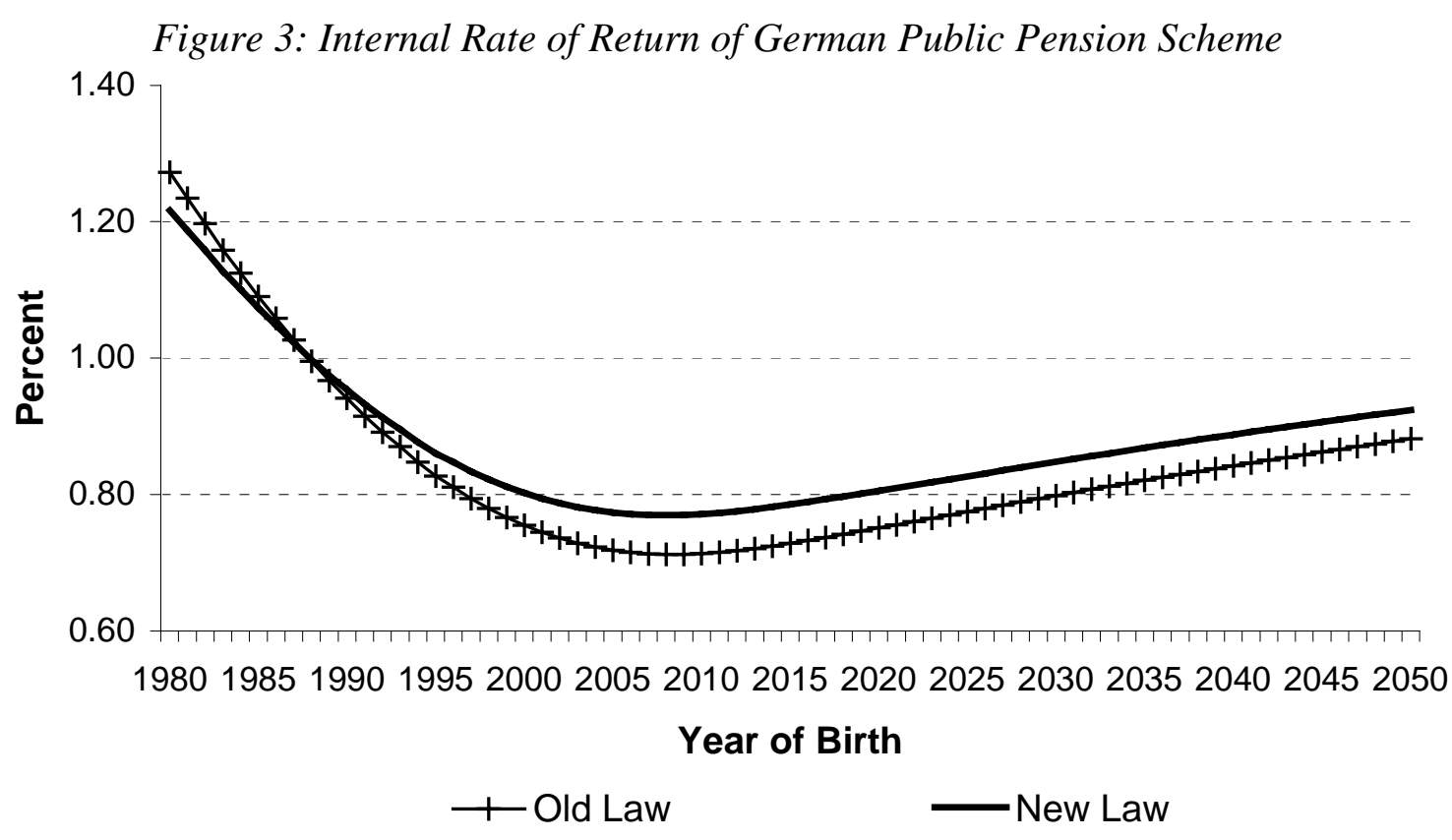

Figure 4: Savings Subsidy and Savings Advantage (in Euro)

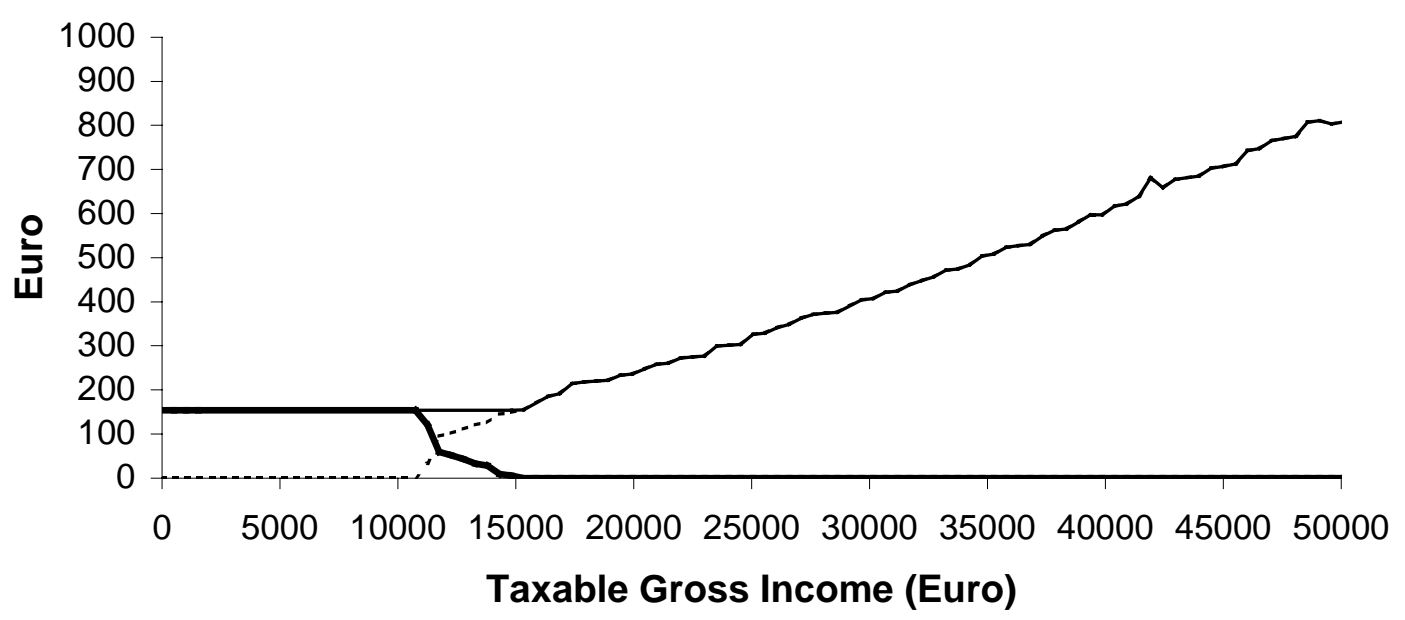

—Effective Subsidy ..... Income Tax Rebate —-Total Savings Advantage Single without children. Income tax and personal pension regulations as valid in 2008 . 
Figure 5: Savings Subsidy and Savings Advantage (\% of savings)

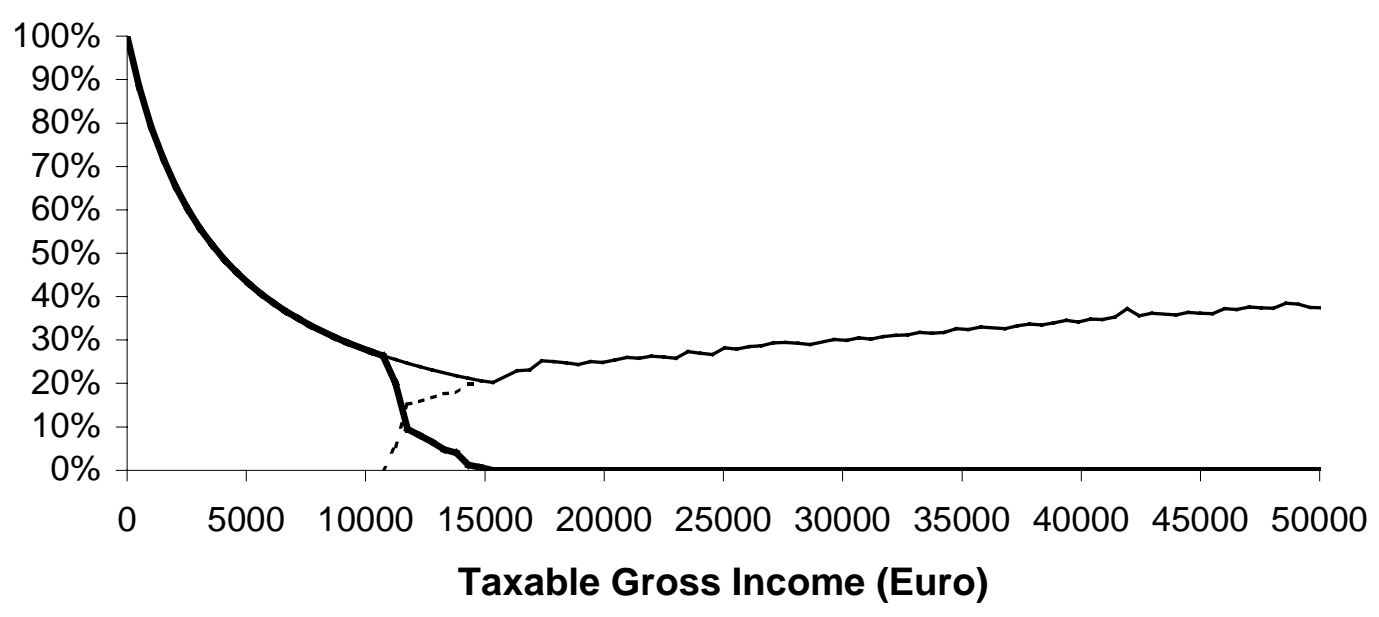

—Effective Subsidy - . . . . - Income Tax Rebate Total Savings Advantage Single without children. Income tax and personal pension regulations as valid in 2008.

Figure 6: Net Replacement Rate Including Capital Pensions

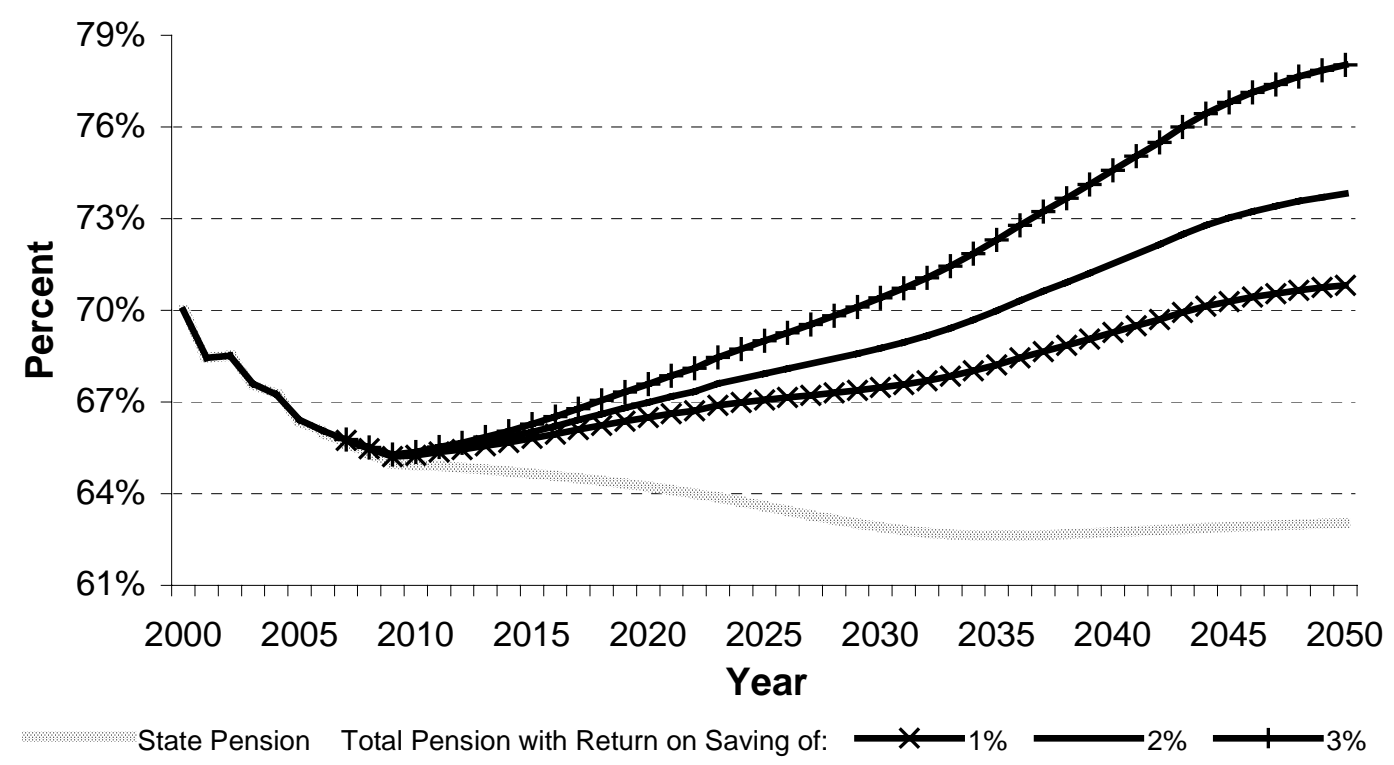




\section{IZA Discussion Papers}

\begin{tabular}{|c|c|c|c|c|}
\hline No. & Author(s) & Title & Area & Date \\
\hline 270 & $\begin{array}{l}\text { B. Augurzky } \\
\text { C. M. Schmidt }\end{array}$ & $\begin{array}{l}\text { The Evaluation of Community-Based } \\
\text { Interventions: A Monte Carlo Study }\end{array}$ & 6 & $03 / 01$ \\
\hline 271 & $\begin{array}{l}\text { B. Augurzky } \\
\text { C. M. Schmidt }\end{array}$ & The Propensity Score: A Means to An End & 6 & $03 / 01$ \\
\hline 272 & $\begin{array}{l}\text { C. Belzil } \\
\text { J. Hansen }\end{array}$ & $\begin{array}{l}\text { Heterogeneous Returns to Human Capital and } \\
\text { Dynamic Self-Selection }\end{array}$ & 5 & $03 / 01$ \\
\hline 273 & G. Saint-Paul & $\begin{array}{l}\text { Distribution and Growth in an Economy with } \\
\text { Limited Needs }\end{array}$ & 5 & $03 / 01$ \\
\hline 274 & $\begin{array}{l}\text { P.J. Pedersen } \\
\text { N. Smith }\end{array}$ & $\begin{array}{l}\text { Unemployment Traps: Do Financial Dis- } \\
\text { incentives Matter? }\end{array}$ & 3 & 03/01 \\
\hline 275 & $\begin{array}{l}\text { G. S. Epstein } \\
\text { T. Lecker }\end{array}$ & $\begin{array}{l}\text { Multi-Generation Model of Immigrant Earnings: } \\
\text { Theory and Application }\end{array}$ & 1 & $03 / 01$ \\
\hline 276 & $\begin{array}{l}\text { B. Amable } \\
\text { D. Gatti }\end{array}$ & $\begin{array}{l}\text { The Impact of Product Market Competition on } \\
\text { Employment and Wages }\end{array}$ & 5 & $03 / 01$ \\
\hline 277 & R. Winter-Ebmer & $\begin{array}{l}\text { Evaluating an Innovative Redundancy-Retraining } \\
\text { Project: The Austrian Steel Foundation }\end{array}$ & 6 & 03/01 \\
\hline 278 & T. M. Andersen & $\begin{array}{l}\text { Welfare Policies, Labour Taxation and Inter- } \\
\text { national Integration }\end{array}$ & 2 & $04 / 01$ \\
\hline 279 & T. M. Andersen & $\begin{array}{l}\text { Product Market Integration, Wage Dispersion } \\
\text { and Unemployment }\end{array}$ & 2 & $04 / 01$ \\
\hline 280 & $\begin{array}{l}\text { P. Apps } \\
\text { R. Rees }\end{array}$ & $\begin{array}{l}\text { Household Saving and Full Consumption over } \\
\text { the Life Cycle }\end{array}$ & 7 & $04 / 01$ \\
\hline 281 & G. Saint-Paul & $\begin{array}{l}\text { Information Technology and the Knowledge } \\
\text { Elites }\end{array}$ & 5 & 04/01 \\
\hline 282 & $\begin{array}{l}\text { J. Albrecht } \\
\text { A. Björklund } \\
\text { S. Vroman }\end{array}$ & Is There a Glass Ceiling in Sweden? & 5 & $04 / 01$ \\
\hline
\end{tabular}



A. Kaul
M. Kolmar Spatial Model of Restricted Labor Mobility to Internal Promotion for Young U.S. Men and Women and the Rising Returns to Skill: US and France 1964-2000 
G. Brunello

C. Lucifora

R. Winter-Ebmer
A. Stutzer
R. Lalive

301
J. R. Frick
G. G. Wagner

H. Bonin
H. Bonin
G. Abío
E. Berenguer
J. Gil
C. Patxot

\section{6/01}

06/01

Economic and Social Perspectives of Immigrant 1

\section{Labour Market Trends in Spain}

Downsizing 

Monetary Appraisal
A. Frederiksen
E. K. Graversen Germany:

Overtime Work, Dual Job Holding and Taxation 

2000 

A. lbourk
B. Maillard
S. Perelman
H. R. Sneessens

The Matching Efficiency of Regional Labour

Markets: A Stochastic Production Frontier

Estimation, France 1990-1995

$340 \quad X$. Wauthy

Y. Zenou

How Does Imperfect Competition in the Labor

3

08/01

Market Affect Unemployment Policies?

$341 \quad$ S. Kohns

Testing for Asymmetry in British, German and

The Virtue of Being Underestimated: A Note on

5

$08 / 01$ Discriminatory Contracts in Hidden Information Models

343

H. Bonin

Will it Last? An Assessment of the 2001 German

3

$08 / 01$

Pension Reform 